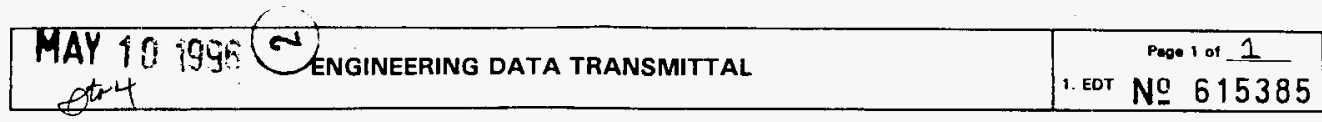

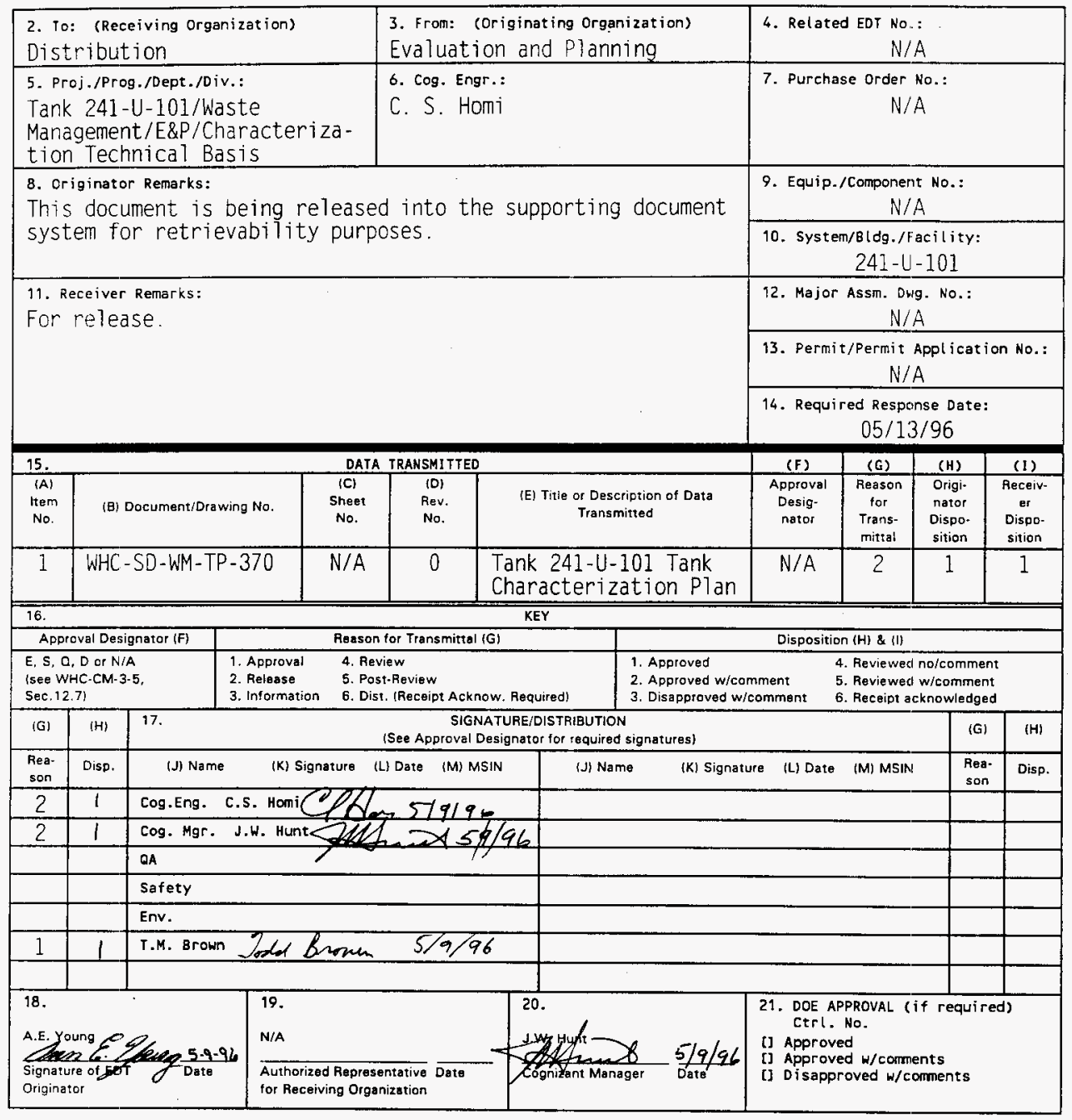

BD-7400-172-2 (04/94) GEF097 


\title{
Tank 241-U-101 Tank Characterization Plan
}

\author{
C. S. Homi
}

Westinghouse Hanford Company, Richland. WA 99352

U.S. Department of Energy Contract DE-AC06-87RL10930

$\begin{array}{lll}\text { EDT/ECN: } & \text { EDT }-615385 & \text { UC: } 2070 \\ \text { Org Code: } & 79200 & \text { Charge Code: N4G6A } \\ \text { B\&R Code: } & \text { EW } 3120074 & \text { Tota? Pages: } 9\end{array}$

Key Words: Characterization, General Safety Issues. Specific Safety Issues. Information Requirements. Schedule

Abstract: This document is a plan that identifies the information needed to address relevant issues concerning short-term and long-term storage and long-term management of single-shel1 tank 241-U-101.

TRADEMARK DISCLAIMER. Reference herein to any specific comercial product, process, or service by trade name, trademark, manufacturer, or otherwise, does not necessarily constitute or imply its endorsement, recommendation, or favoring by the United States Government or any agency thereof or its contractors or subcontractors.

Printed in the United States of America. To obtain copies of this document, contact: WHC/BCS Document Control Services, P.O. Box 1970, Mailstop H6-08, Richland WA 99352, Phone (509) 372-2420; Fax (509) 376-4989.
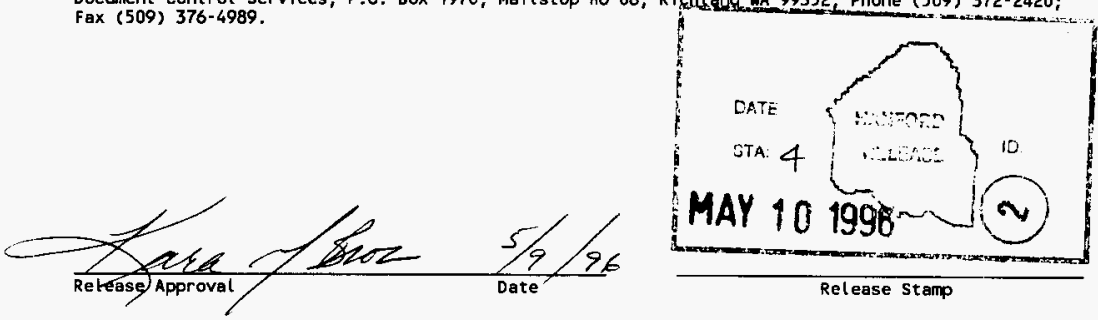

\section{Approved for Public Release}


WHC-SD-WM-TP-370

Revision 0

UC-2070

\section{Tank 241-U-101 \\ Tank Characterization Plan}

T. M. Brown

Westinghouse Hanford Company

Date Published

May 1996

Prepared for the U.S. Department of Energy

Office of Environmental Restoration and

Waste Management

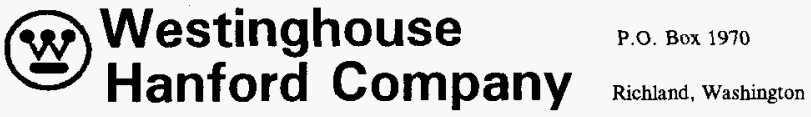

Management and Operations Contractor for the

U.S. Department of Energy under Contract DE-AC06-87RL10930

Approved for Public Release 


\section{WHC-SD-WM-TP-370, REV 0}

\section{TABLE OF CONTENTS}

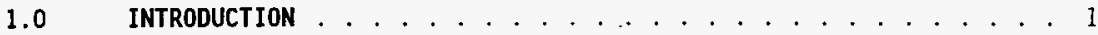

2.0 PROGRAM ELEMENTS REQUIRING INFORMATION FOR TANK 24I-U-101 . . . . 2

2.1 GENERAL SAFETY ISSUES . . . . . . . . . . . . 2

2.2 SPECIFIC SAFETY ISSUES . . . . . . . . . . . . . 2

2.2.1 Ferrocyanide ............... 2

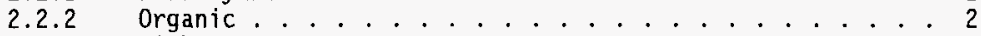

2.2 .3 High Heat ............... 2

2.2.4 Flammable Gas ................. 2

2.2 .5 Vapor................ 2

2.2 .6 Criticality. . . . . . . . . . . 3

2.3 CONTINUING OPERATIONS $\ldots \ldots \ldots$

2.3.1 Compatibility/Stabilization ........... 3

2.3.2 Evaporator ................ 3

2.4 DOUBLE-SHELL TANK WASTE ANALYSIS PLAN ........... 3

2.5 DISPOSAL . . . . . . . . . . . . . . . . 3

2.5.1 Retrieval ................ 3

2.5.2 Pretreatment/vitrification . . . . . 3

2.6 HISTORICAL MODEL EVALUATION . . . . . . . . . . . 3

3.0 HOW INFORMATION WILL BE OBTAINED ............. 4

4.0 PRIORITY OF INFORMATION REQUIREMENTS .............. 4

5.0 WHEN INFORMATION WILL BE AVAILABLE ........... 4

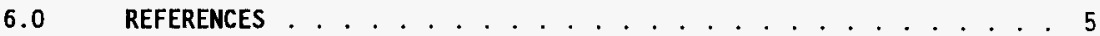

\section{LIST OF TABLES}

4-1 Integrated DQO Requirements and Priorities.......... 4 


\subsection{INTRODUCTION}

This Tank Characterization Plan (TCP) identifies the information needed to address relevant issues concerning short-term and long-term safe storage and long-term management of single-shell tank 241-U-101 (U-101). It should be understood that the various needs and issues surrounding tank U-10l are evolving as new information about the tank is uncovered. As a result of this progression, this TCP addresses only the issues that, to this date, have been identified. It is expected that deviations from this plan may occur as additional issues or needs arise which impact the management of tank U-10I. As necessary, this TCP will be revised to reflect those changes or deviations. This plan reflects the best information available as of May 1996.

Tank 241-U-101 was filled with metal waste from the first quarter of 1946 until the first quarter of 1957. The tank was sluiced in the second quarter of 1955 and in the third quarter of 1956. The tank was declared empty in the first quarter of 1957 and was filled with Reduction Oxidation (REDOX) waste the following quarter. In the second quarter of 1978, the waste was classified as non-complexed. The tank contained 6 cask loads of experimental fuel elements; shroud tubes and samarium "poison" ceramic balls; $1,530 \mathrm{~g}$ of $4.5 \%$ enriched uranium and $6 \mathrm{~g}$ of plutonium; $180 \mathrm{Ci}$ of ${ }^{60} \mathrm{Co}$ and $130 \mathrm{Ci}$ of mixed fission products; ${ }^{60} \mathrm{Co}$ slugs with $70 \mathrm{Ci}{ }^{60} \mathrm{Co}$. Presently, the waste is classified as noncomplexed. The tank was removed from service and labeled an assumed leaker with a 30,000-gal loss in 1959. It was partially isolated in 1978 and interim stabilized in September 1979. Intrusion prevention was completed in September 1982 (Brevick et al. 1995).

Tank U-101 currently contains a total waste volume of $95 \mathrm{~kL}$ (25 kgal), which is equivalent to $11.5 \mathrm{~cm}(4.5 \mathrm{in})$ of waste as measured from the baseline of the tank (Hanlon 1996).

This tank is not on any Watch List.

Near-term sampling and analysis activities are focused on either verifying or changing the Watch List tank status, and identifying any new safety issues. Should any safety issues be identified, additional analysis will occur consistent with the identified issue.

In addition to the resolution of the safety issues, it is intended that all tank waste will be subject to pretreatment and retrieval to prepare for final storage or disposal. Presently, these long-range plans have yet to be fully identified and are, therefore, not included in this document. 
WHC-SD-WM-TP-370, REV 0

\subsection{PROGRAM ELEMENTS REQUIRING INFORMATION FOR TANK 241-U-101}

This section identifies the various program elements, and identifies which of these programs require characterization data from tank U-101.

\subsection{GENERAL SAFETY ISSUES}

The Tank Safety Screening Data Quality Objective (Dukelow et al. 1995) describes the sampling and analytical requirements that are used to screen waste tanks for unidentified safety issues. Analytical requirements for the safety screening of a tank are energetics, total alpha activity, moisture content, density, and $\mathrm{flammable} \mathrm{gas} \mathrm{concentration.}$

\subsection{SPECIFIC SAFETY ISSUES}

\subsubsection{Ferrocyanide}

This tank is not on the Ferrocyanide Watch List; therefore, no information needs are currently identified for this program element.

\subsubsection{Organic}

This tank is not on the Organic Watch List; therefore, no information needs are currently identified for this program element.

\subsubsection{High Heat}

This tank is not on the High Heat Watch List; therefore, no information needs are currently identified for this program element.

\subsubsection{Flammable Gas}

This tank is not on the $\mathrm{Flammable} \mathrm{Gas} \mathrm{Watch} \mathrm{List;} \mathrm{therefore,} \mathrm{no} \mathrm{information}$ needs are currently identified for this program element.

\subsubsection{Vapor}

A11 177 underground tanks must be vapor-sampled for organic solvent screening as per Recommendation 93-5 Implementation Plan (DOE-RL 1996). Some tanks may require additional vapor sampling due to other program needs. These tanks may be classified into four categories: (1) those tanks which are to be rotary mode core sampled (as a consequence of the rotary sampling system exhaust permit requirements); (2) tanks on the Organic or Ferrocyanide Watch Lists; (3) tanks in $C \mathrm{farm}$; and (4) tank 241-BX-104, due to vapor exposure. Information needs must satisfy Data Quality Objectives for Tank Hazardous Vapor Safety Screening (Osborne and Buckley 1995), and for rotary mode only, Rotary Core Vapor Sampling Data Quality Objective (Price 1994), and Data Quality Objective for Regulatory Requirements for Hazardous and Radioactive Air Emissions Sampling and Analysis (MuTkey and Markillie 1995) as amended by Status of the Current Understanding of 
WHC-SD-WM-TP-370, REV 0

the Toxic Air Pollutants (TAPS) and Hanford Tank Farm Vapor Space Characterization; Recommended Path Forward and Just ification for Continued RMCS Exhauster Operations (Laws 1996).

\subsubsection{Criticality}

No information separate from that for the general safety issue of tank U-101 are currently identified for this program element. However, if the general safety screening of tank $\mathrm{U}-101$ identifies a potential criticality concern, analyses for fissile materials and neutron sorbers and poisons will be performed as identified in the safety screening data quality objective (DQO).

\subsection{CONTINUING OPERATIONS}

\subsubsection{Compatibility/Stabilization}

This section does not apply to tank U-10l.

\subsubsection{Evaporator}

This section does not apply to tank U-101.

\subsection{DOUBLE-SHELL TANK WASTE ANALYSIS PLAN}

This section does not apply because tank $U-101$ is a single-shell tank.

\section{$2.5 \quad$ DISPOSAL}

\subsubsection{Retrieval}

Current retrieval needs (Bloom and Nguyen 1995) do not call for test samples to be taken from tank U-101.

\subsubsection{Pretreatment/Vitrification}

Tank $U$-101 has not been identified as a bounding tank for pretreatment/ disposal process development strategy (Kupfer et a1. 1995). All tanks were prioritized using the pretreatment strategy in the Tank Waste Characterization Basis (Brown et a1. 1995) document and a portion of archive sample material could be used for pretreatment testing if available. The strategy does not require any specific analyses to be done on the samples.

\subsection{HISTORICAL MODEL EVALUATION}

Bounding tanks and data requirements for historical model evaluations are found in Historical Model Evaluation Data Requirements (Simpson and McCain 1995). Tank $U-101$ is not identified as a primary bounding tank for historical mode 1 evaluations. 


\subsection{HOW INFORMATION WILL BE OBTAINED}

The number of samples required to characterize a tank is a function of waste heterogeneity and the desired confidence to make a correct decision. As directed by the safety screening $\mathrm{DQO}$, if inadequate information exists to determine an appropriate number of samples, two vertical profiles will be obtained. These vertical profiles may be obtained using core, auger (for shallow tanks), or grab samples. If analysis of these profiles reveals that additional profiles are necessary to meet data needs, more sample profiles will be requested.

\subsection{PRIORITY OF INFORMATION REQUIREMENTS}

Vapor sampling is scheduled for February 1998. Grab sampling is scheduled for June 1996. Auger sampling is scheduled for March 1997 (Stanton 1996). Refer to Table 4-1 for the current DQO requirements and planned sampling and analys is requirements.

Table 4-1: Integrated DQO Requirements and Priorities

\begin{tabular}{||l|l|l|l||}
\hline $\begin{array}{l}\text { Sampling } \\
\text { Event }\end{array}$ & \multicolumn{1}{|c|}{ Applicable DQ0 } & Sampling Requirements & \multicolumn{1}{|c|}{$\begin{array}{c}\text { Analytical } \\
\text { Requirements }\end{array}$} \\
\hline $\begin{array}{l}\text { Vapor } \\
\text { Sampling }\end{array}$ & $\begin{array}{l}\text {-Organic Solvent } \\
\text { Layer 93-5 Vapor } \\
\text { Issue } \\
\text {-Hazardous Vapor } \\
\text { DQ0 }\end{array}$ & $\begin{array}{l}\text { Steel canisters, } \\
\text { Triple Sorbent Traps, } \\
\text { Sorbent Trap Systems. }\end{array}$ & $\begin{array}{l}\text { Flammable Gas } \\
\text { Organic Vapors } \\
\text { Permanent Gases }\end{array}$ \\
\hline $\begin{array}{l}\text { Grab } \\
\text { Sampling }\end{array}$ & $\begin{array}{l}\text {-Safety Screening } \\
\text { DQ0 }\end{array}$ & $\begin{array}{l}\text { Grab samples from 2 } \\
\text { risers separated } \\
\text { radially to the } \\
\text { maximum extent } \\
\text { possible. } \\
\text { Combustible gas } \\
\text { measurement. }\end{array}$ & $\begin{array}{l}\text { Flammability, } \\
\text { Energetics, Total } \\
\text { Alpha activity, } \\
\text { Specific Gravity. }\end{array}$ \\
\hline
\end{tabular}

* Consult each applicable DQ0 in force at the time for sampling and analytical requirements.

** The auger sampling event is not included in this table because it is believed that grab sampling should be able to meet the needs of the safety screening DQO.

\subsection{WHEN INFORMATION WILL BE AVAILABLE}

According to Stanton (1995), data are expected to be available from the grab sampling event for tank $U-101$ in October 1996. The vapor sampling data are expected in April 1998. If auger sampling is conducted, data are expected in July 1997. These times may be altered if the sampling schedule changes. 


\section{WHC-SD-WM-TP-370, REV 0}

\subsection{REFERENCES}

Bloom, G. R. and Q. H. Nguyen, 1995, Characterization Data Needs for Development, Design and Operation of Retrieval Equipment Developed Through the Data Quality Objective Process, WHC-SD-WM-DQO-008, Rev. 0, Westinghouse Hanford Company, Richland, Washington.

Brevick, C. H., L. A. Gaddis, and E. D. Johnson, 1995, Supporting Document for the Southwest Quadrant Historical Tank Content Estimate Report for $U$ Tank Farm, Vol I, WHC-SD-WM-ER-325, Rev. 0, Westinghouse Hanford Company, Richland, Washington.

Brown, T. M., S. J. Eberlein, and T. J. Kunthara, 1995, Tank Waste Characterization Basis, WHC-SD-WM-TA-164, Rev. 1, Westinghouse Hanford Company, Richland, Washington.

DOE-RL, 1996, Recommendation 93-5 Implementation P7an, D0E/RL-94-0001, Rev. 1, U.S. Department of Energy, Richland, Washington.

Dukelow, G.T., J.W. Hunt, H.Babad, and J.E. Meacham, 1995, Tank Safety Screening Data Quality Objective WHC-SD-WM-SP-004, Rev 1, Westinghouse Hanford Company, Richland, Washington.

Hanlon, B.M., 1996, Waste Tank Summary for Month Ending January 31, 1996, WHC-EP-0182-94, Westinghouse Hanford Company, Richland, Washington.

Kupfer, M. J., W. W. Schultz, and J. T. Slankas, 1995, Strategy for Sampling Hanford Site Tank Wastes for Development of Disposal Technology, WHC-SD-WM-TA-154, Rev. 1, Westinghouse Hanford Company, Richland, Washington.

Laws, G. L., 1996, Status of the Current Understanding of the Toxic Air Pollutants (TAPS) and Hanford Tank Farm Vapor Space Characterization; Recommended Path Forward and Justification for Cont inued RMCS Exhauster Operations, (telephone conference memorandum 01830-96-022, to Distribution, March 8), Westinghouse Hanford Company, Richland, Washington.

Mulkey, C.H., and K. D. Markillie, 1995, Data Quality Objective for Regulatory Requirements for Hazardous and Radioactive Air Emissions Sampling and Analysis, WHC-SD-WM-DQ0-021, Rev. 0, Westinghouse Hanford Company, Richland, Washington.

Osborne, J. W., and L. L. Buckley, 1995, Data Qua7ity Objectives for Tank Hazardous Vapor Safety Screening, WHC-SD-WM-DQ0-002, Rev. 2, Westinghouse Hanford Company, Richland, Washington.

Price, D. N., 1994, Rotary Core Vapor Sampling Data Quality Objective, WHC-SD-WM-SP-003, Rev. 0, Westinghouse Hanford Company, Richland, Washington. 
Simpson, B. C., and D. J. McCain, 1995, Historical Model Evaluation Data Requirements, WHC-SD-WM-DQO-018, Rev. OA, Westinghouse Hanford Company, Richland, Washington.

Stanton, G. A., 1996, Baseline Sampling Schedule, Change 96-02 (Internal memo 75610-96-06 to Distribution, April 1996), Westinghouse Hanford Company, Richland, Washington. 


\section{DISTRIBUTION SHEET}

\begin{tabular}{|c|c|c|c|c|c|}
\hline To & \multirow{2}{*}{\multicolumn{3}{|c|}{$\begin{array}{l}\text { From } \\
\text { Evaluation and Planning }\end{array}$}} & \multicolumn{2}{|l|}{ Page 1 of 1} \\
\hline Distribution & & & & \multicolumn{2}{|c|}{ Date $\quad 05 / 09 / 96$} \\
\hline \multicolumn{4}{|l|}{ Project Title/Work Order } & \multicolumn{2}{|c|}{ EDT No. EDT-615385 } \\
\hline \multicolumn{4}{|c|}{$\begin{array}{l}\text { WHC-SD-WM-TP-370, Rev. 0, "Tank 241-U-101 Tank Characterization } \\
\text { Plan" }\end{array}$} & \multicolumn{2}{|l|}{ ECN No. $\quad N / A$} \\
\hline Name & MSIN & $\begin{array}{c}\text { Text } \\
\text { with } \\
\text { All } \\
\text { Attach. }\end{array}$ & Text Only & $\begin{array}{c}\text { Attach./ } \\
\text { Appendix } \\
\text { Only }\end{array}$ & $\begin{array}{l}\mathrm{EDT} / \mathrm{ECN} \\
\text { Only }\end{array}$ \\
\hline
\end{tabular}

\section{ONSITE}

U. S. Department of Energy -

Richland Field Office

W. Liou

N. W. Willis

$\begin{array}{ll}57-54 & X \\ 57-54 & X\end{array}$

Westinghouse Hanford Company

T. M. Brown

G. D. Forehand

C. S. Homi

Central Files

T.C.R.C.

$\begin{array}{ll}\text { R2 }-12 & X \\ \text { S7 }-21 & X \\ \text { R2 }-12 & X \\ \text { A3 }-88 & X \\ \text { R2 }-12 & X\end{array}$

\section{DFFSITE}

U. S. Department of Enerqy - Headquarters

Office of Environmental Restoration and Waste Management EM-563

12800 Middlebrook Road

Germantown. MD 20874

J. A. Poppiti 